\title{
The Condition and it's Control of Present Administrative Costs of China
}

\author{
Xiaoming Qiao ${ }^{1, \text { a }}$ \\ ${ }^{1}$ Journal Editorial Department, Yunnan Normal University, Yunnan, Kunming, 650092 \\ ${ }^{a}$ email
}

\begin{abstract}
Keywords: Administrative Costs; Civil Service; Financial Establishment; Democratic and Legislative Government
\end{abstract}

\begin{abstract}
Our administrative expense is in the first level in the world which not consist with our goal of building probity and diligent government, it is imminent to control the cost. The practical and objective factors that institutional settings, staffing and lack of scientific decision- making make the administrative cost is much high. The governments and staffs are in the poor awareness about administrative cost in the high state. It needs their help to government internal and external forces to ensure administrative costs at a reasonable range, so as to achieve Chinese national rejuvenation dream well and quickly.
\end{abstract}

\section{Introduction}

Since the current staff of administrative cost consciousness, resulting in administrative extremely common phenomenon of irrational consumption, coupled with the government itself provided in institutions, other financial aspects of budgeting and administrative oversight mechanisms, etc. there is a big loophole, eventually led to the country administrative costs have been in a high state. Compared to other developed countries in Europe and America, our administrative costs far exceeded the warning level of developed countries in Europe and America, has seriously affected the effective operation of our administration. China's central government has realized the importance of controlling administrative costs, therefore eighteen Third Plenary Session of the specification "Three" anti-corruption measures are for the use of funds, but also achieved some success, but still fundamentally solve administrative problem of high costs. Therefore, I chose the administrative costs of this article as a starting point, mainly for the current situation in our increasingly high administrative costs and administrative costs were high because the analysis before proposing control measures is according to reason, in order to promote better and faster administrative costs perfect mechanism.

\section{The Necessity to Improve the Administrative Cost}

Administrative costs at a relatively reasonable range, conducive to political democratization, improve the scientific and democratic decision-making of the government, the degree of enhancement of cooperation between the government and citizens; to improve the decision-making level of the need for effective control of administrative costs.

The economy needs a good political system guarantee, reasonable administrative cost control mechanisms, can improve economic investment and financing environment, expand economic development channels and methods, activating vitality of the private economy, to further improve the market system, and better for the economy healthy run escort.

Politics and culture are mutually reinforcing. Public and private part of the cultural tradition of thinking in the minds of the administrative body is formed in the present situation, so that they confused the relationship between public interest and private interest, and thus poses a threat to the public interest [1]. Public and private cultural norms of rational planning depend on the administrative costs.

Enterprise management process can not avoid negotiations with the government. As one corporate administrative costs borne by, changes in the status of the administrative costs, in addition 
to the government to reduce the burden for the development of enterprises, but also to improve their administrative efficiency of enterprises and promote the development of enterprises.

It is the link between social groups linked to the government and citizens. Changes in administrative costs, to a certain extent, increase transparency and community groups work norms, improve the internal management of social organizations, social organizations to improve the external image, improve efficiency and social organizations social service.

It is the people who bear the administrative costs directly. Administrative costs are people costs for public services provided by the government paid, mainly to pay various taxes paid. If a reasonable level of administrative costs, it can improve people's trust in the government, in order to stimulate people to participate in the political life of the initiative.

The administrative costs are financial means for the government to perform government, changes in administrative costs and affect people's administrative burden in the political area, appropriate adjustments to administrative costs and reduce their administrative burden, while allowing the government to use administrative funds to strengthen the recreational facilities, rich people amateur entertainment. Comments from people on administrative activities feedback strength point of view, control administrative costs imminent.

\section{The Analysis of Administrative Costs Availability}

Table 1. China administrative expenses as a percentage of national expenditure (\%)

\begin{tabular}{|c|c|c|c|c|}
\hline Year & 1990 & 1995 & 2000 & 2005 \\
\hline Ratio & 13.44 & 14.60 & 17.42 & 19.19 \\
\hline
\end{tabular}

Source: "China Statistical Yearbook 2006"

As can be seen from the figure, the administrative costs of the national accounts for the high proportion of total financial expenditure, and continue to show increasing trend. In recent years, our investment in administrative relatively high public expenditure is relatively high government spending on public works, public services and public utilities administrative expenses far beyond the cost of American and European countries. According to a set of data CPPCC National Committee members, Mr. Ren Yuling provides evidence that: "From the reform and opening up 1978 - 200325 years, the Chinese administrative expenses has increased 87 times, and in recent years the average growth of $23 \%$ per year, administrative costs accounted for the proportion of total expenditure in 2003 has risen to 19.03\%, compared with 2.38\% in Japan, the United Kingdom 4.19\% South Korea 5.06\%, France 6.5\%, Canada 7.1\% United States 9.9\% higher, respectively $16.65,14.84,13.97,12.53,11.93$ and 9.13 percentage points in 2005 alone, bus consumption, public funds, public funds to travel up to three add up to 6000 billion RMB, accounting for 20 percent of state revenues, the equivalent of universal compulsory education investment of 5 times that China has become the world's countries with the highest administrative costs. "[2] In Case of Foreign Affairs, Ministry of Foreign Affairs in 2012 expenditure amounted to 5.79 billion RMB. American and European countries the proportion of basic administrative costs expenditure at $15 \%$ or less, since 2000. Our administrative expenses are more than $15 \%$ per year, reached its highest at $24 \%$, our administrative costs significantly higher than in other countries of the world. Thus, our administrative costs remained at a high level state, seriously affected the improvement of administrative efficiency.

\section{The Reasons for the High Administrative Costs}

Preparation of expansion (a) institutional, financial support of the population, high wage costs. China's vast territory, large population, the number of civil servants is greater demand, resulting in the large number of government employees. In 2011 the number of civil servants reached 702.1 million in 2012 rose to 7.089 million, to continue to rise in 2013 to 7.171 million, remained rising growth trend, which does not include the staff of financial institutions within the government establishment. Governments bear the huge cost of salaries of civil servants and other government enjoy staffing groups and various other benefits costs, coupled with the difficulty of large 
institutional settings exist, people set unreasonable phenomenon is widespread, fiscal burden of government virtually back on the increase.

Push public funds and other mixed public and private behavior. Civil servants by frequent public property for private events, public funds gray consumption phenomenon after another. Government official vehicles configuration excessive overstaffing phenomenon more often than not, some government workers often caused due to personal psychological comparisons. Government workers are often under the guise of reporting on behalf of the meeting were received - Celebration Entertainment - Recreation - specialty "line" of additional consumption. In addition, cross-border regional "double cross" junket is commonplace. Government "Three funds" irrational use of waste caused by the black hole is one of the factors contributing to the high administrative costs of consumption.

Lack of administrative examination and approval authority of the government workers too centralized and regulatory system itself is an important reason for financial fund management loopholes. In recent years, often occurs under the guise of the name of the false claims of scientific research, illegal transfers, misappropriated research funding corruption, a series of mass of corruption at the local government debt, the protection of housing finance and expenditure management and financial management and other aspects of mineral resources case, all indicating that the market system is not perfect initiators budget of arbitrary and unreasonable financial structure, leading to the distribution of social resources, lack of scientific planning, allocation and use of administrative property deviate from the institutionalization of the track and push up the cost of inputs and the use of administrative one of the important reasons.

Administrative transparency The Government is not enough and the low level of government spending is disclosed. 2002 outbreak of "SARS" has become China's information disclosure turning point that brought to the government information disclosure of China's political arena. China began to implement the May 1, 2004 the government information disclosure system, trying to create a "to the principle of transparency and administrative openness" sunshine government, but because the concept of administrative procedures, failed to effectively change the way, as well as government agencies too "authoritarian" is a low degree of attention, lack of uniformity and coordination of activities of the executive government is limited only in the government system, government affairs channel is not smooth, and ultimately lead to "the principle of open, not open to exception," the Chief information disclosure principles can not be effectively implemented. Therefore, the low level of external public government office is one of the causes of the increasingly high cost of government administration.

Financial System resistance, government reform is not in place. Budget and restructuring of government is an important part of government reform, China's current fiscal system "money" reform the reform has achieved great success, but "political" reform but did not achieve the same degree of effect, which is due to financial establishment and the government is closely related to the political system, government fiscal reform did not pay enough attention and support to the financial system reform faces many obstacles. In addition, due to the lack of experience in the financial system reform, the lack of overall financial operation of the process and financial supervision mechanism, which has virtually pushed up administrative costs in China.

\section{The Recommendations for Improving the Administrative Costs}

Sense of administration costs, strengthen the "cost management." While providing measurable output, the government agencies rather than private companies spend higher unit costs [3]. Administrative costs of civil servants awareness is weak, "Three funds," the unreasonable use of common administrative consumer behavior of civil servants administrative costs increased more invisible consumption. Therefore, China in July 2014 launched a comprehensive reform of the bus. Official vehicles mainly three kinds of vehicles including professional cadres car, general duty law enforcement official cars and, the object of this bus reform is directed at vice-ministerial level cadres car and the following general official vehicles. The main content is to abolish the general public service vehicles, official vehicles ordinary travelers' socialization, and timely payment of 
public transport subsidies. Simultaneously achieve a variety of policies to prevent "both subsidies and take the bus" to reduce the hidden perks of civil servants. About subsidy standards, divided into three levels: the central and state organs: Secretaries $1300 \mathrm{RMB}$ per person per month, $800 \mathrm{RMB}$ per person per month division level, section level and below 500 RMB per person per month; the place: shall not high the central subsidy standard of 130\%; frontier minority areas and other remote areas of central subsidies shall not exceed the standard 159\%. Cancel bus, mainly through public auction, public tender auction mechanism to assess, after deducting expenses related to income taxes to the state treasury. The amount of subsidy hierarchical and auction proceeds into the government treasury is to reduce equipment costs, directly reflects the basic cost management. These specific measures to regulate the administrative conduct of government staff, reduce the occurrence of unreasonable administrative consumer behavior, so as to achieve the purpose of reducing administrative costs.

Set up regulatory bodies to streamline personnel. One way to avoid bloated and redundant clerical staff is effective way to control administrative costs. The past 30 years, China has carried out seven functional departments of the State Council on restructuring. State Council departments reduced to 59 from 100, and then reduced to 59 from 25 today. March 2013, China's implementation of the composition of most of the reform of the State Council, through the National Health and Family Planning Commission, China Food and Drug Administration, the State Press and Publication Administration of Radio, Film and Television, the State Oceanic Administration and the National Energy Bureau restructuring, and implementation of separating railway, the original 27 State Council departments reduced to 25, and further to avoid the bloated and clerical staff redundant. Preparation and staff be increased wage costs supernumerary staff of the already high cost of living higher. There is an urgent need to put a number of matters referred to the contents of a similar department jurisdiction, as far as possible to curb the cross-government functions, policies from different departments, bull management, so as to quantify administrative resources, better reduce administrative costs and improve administrative efficiency.

The transformation of government functions, establishing administrative oversight mechanisms consumption. An administrative official corruption arising from ambiguous public spending and investment, is one of the causes to induce the high administrative costs, it is necessary to accelerate the transformation of government functions, improve administrative oversight mechanisms consumption, and further improve inter-administrative civil servants consumer visibility. Since the eighth session of the Third Plenary, the party and the country have been promoting the "Democratic Government by Law honest and diligent" and high strength and intensity of the monitoring of the administrative officials of the executive act of the requirements is unprecedented, combining scientific performance evaluation system, the establishment of effective performance management system budget. By the government's administrative costs as one of the assessment indicators of civil servants, change too much emphasis on "GDP" of the traditional way of government performance appraisal action, citing competition examination recruitment and other enterprise management mode, the implementation of the civil service "accountability system", by established civil servants administrative behavior tracking feedback evaluation mechanism in order to "who work, who is responsible," the responsibility of tracking method fundamentally avoid privatization of civil servants administrative activities, more scientific and government decision-making, reduce government failures in the decision-making process, decision-making more accountable, democratic and normative.

Strengthen the government's budgetary mechanisms and improve administrative expenses cost accounting system. The purpose of standardized financial budget system is to save administrative costs, but handled properly, some of the institutional provisions have actually become an endless-consuming administrative cost gap [4]. October 2014, "the decision on the reform of institutions of staff pension system bodies" by the unit gross wage $20 \%$ contributions and personal schedule individual contributions wage of social pooling and individual accounts $8 \%$ contribution of combining the basic pension insurance system, a complete end to the two-track pension age, while the merger of the pension system ushered in a new era. Pension merger financial system so 
that the staff within the establishment to pay the pension shift from financial to eat rice to the basic pension and individual pension accounts of combining social old-age pension to replace the units, civil servants officially bid farewell to the "golden rice bowl." Adjust the pension system, the government directly and effectively reduced administrative costs, to some extent, is to deepen administrative reform and strengthen government budgets reflect a strong mechanism. In addition, efforts to improve the "Government Procurement Law" and strictly enforced, and strengthen government procurement management costing mechanism for sound administration of great significance. Our Government procurement system is not clear, the lack of interoperability and other issues, budget and management of government procurement standards and institutional lack of supervision is likely to cause administrative expenditure of random, is not conducive to administrative cost management. In order to improve the government procurement mechanism, in February 2015 the Ministry of Finance began to push the reform of the government procurement system, and intends to introduce the PPP mode procurement management work among governments and social capital to promote cooperation in order to improve the government procurement management, to further standardize government cost accounting mechanisms .

Reference corporate incentive and restraint mechanisms, resource utilization performance-based rewards and punishments, through positive and negative incentives suppressed effectively regulate and control of administrative acts, reduce administrative costs [5]. The greatest feature is that business competition, the competition mechanism of enterprises is the impetus for enterprises to continue upgrading through this competition mechanism to break the government monopoly of administrative acts to "public-private" or "JV father" of cooperation to regulate the government and administrative behavior of its staff. At the same time the positive development of "e-government" by providing a public network service platform, using the electronic office automation platform, resource sharing and collaboration across geographies administration, simplifying administrative work processes to reduce administrative human resources, public resources for the public waste of resources and facilities. With the electronic network platform while extensive collection of public opinion, strengthen communication and efficiency of the government and the citizens and reduce the administrative cost of communication between the two, in order to quickly meet the administrative needs of citizens, improve the degree of open government act to reduce black-box operation, optimization government social services. In China, such as e-government development in Guangdong, Zhejiang and other developed areas than in the past has made considerable achievements in development of e-government is still a great need for further introduction of the lessons of developed countries to improve the operating procedures and government network service system, achieve better control of administrative expenses and optimize the integration of the public service system.

With the "four-one" supervision system is to monitor all government administrative budget and expenditure management. Social, business, markets and the public as an "exogenous variables" are those who enjoy the government's public service, but also for the government to assume the role of public service pay and social groups and civil organizations of political participation and conversion improving administrative capacity and have a role in promoting. "Small government, big society" positioning mode management and diversification of government service object is an effective means of constraint administrative job consumption, social, markets, businesses and the public as a sound administrative cost external monitoring mechanism for the implementation, use of radio, film and television and other emerging electronic media and newspapers, magazines and other traditional media supervise the work of the administrative operations, administrative operations specific government operations more institutionalized, and responsibility of the public, at the same time have to content regulation, methods, processes and requirements to make specific provisions. In addition, they need to be complemented by "up and down linkage" system to protect government agencies, such as a reference to the approval and supervision of joint responsibility lifelong responsibility for lifelong accountability and subject to safeguards under supervision system of government activities the effective conduct more thorough administrative acts of government and its staff constraints. 


\section{Conclusion}

High administrative costs of our country directly or indirectly affect the effective operation of our political, economic and various other aspects. Establish reasonable administrative cost control mechanisms, reduce administrative costs, to create a clear responsibility, codes of conduct, strict management, clean and efficient integration of democracy and legal government, so that the economy is running smoothly, the political system transformation, increasingly high levels of social services necessary requirement, but also for the early realization of the great Chinese dream plays a catalytic role.

\section{References}

[1] Chen Yongsen, Zhu Wuxiong. Cost dilemma public and private cultural and public administration [J]. Social Sciences, 2008 (06): 55.

[2] "China Youth Daily" March 6, 2006.

[3] Dennis .C Mueller. Public Choice Theory (Chinese Edition)[M]. Beijing: China Social Sciences Press, 1999: 409.

[4] Zhu Wenxing, Zhu Yongtao. The high administrative costs of Economic Analysis and Countermeasures[J]. National School of Administration, 2004 (03): 52.

[5] Jiao Jianguo. Reduce administrative costs: the urgency, importance and fundamental way [J]. reform, 2003 (04): 104. 